\author{
ROBERT HANCZARUK ${ }^{1}$, WOJCIECH BĄBA ${ }^{2}$ \\ ${ }^{1}$ Instytut Biologii, Biotechnologii $i$ Ochrony Środowiska \\ Wydział Nauk Przyrodniczych \\ Uniwersytet Ślaski $w$ Katowicach \\ Jagiellońska 28, 40-032 Katowice \\ ${ }^{2}$ Zakład Badan i Rozwoju \\ Instytut Ekologii $i$ Terenów Uprzemysłowionych \\ Kossutha 6, 40-844 Katowice \\ E-mail: roberthanczaruk@gmail.com \\ wojciech.baba12@gmail.com
}

\title{
ZAGROŻENIA I OCHRONA CENNYCH SIEDLISK PRZYRODNICZYCH W POLSCE NA PRZYKEADZIE MURAW KSEROTERMICZNYCH
}

\section{WSTEP}

Murawy kserotermiczne (Festuco-Brometea) to bogate gatunkowo zbiorowiska trawiaste o charakterze stepowym, spotykane głównie w południowo-wschodnich i południowych rejonach Europy, zaś ekstrazonalnie na terenie całej Europy. Występuja one w miejscach silnie nasłonecznionych, często o wystawie południowej, południowo-wschodniej lub południowo-zachodniej i suchym, zasobnym w węglan wapnia podłożu. W Polsce zbiorowiska kserotermiczne obejmuja w większości płaty niewielkie powierzchniowo. Wystepuja one w znacznym rozproszeniu: w południowo-wschodniej (Niecka Nidziańska, Wyżyna Kielecko-Sandomierska i Lubelska), południowej (Wyżyny Krakowska, Krakowsko-Częstochowska, Śląska, Pieniny Zachodnie, Skalice Nowotarskie i Spiskie), południowo-zachodniej (Pogórza Kaczawskie i Wałbrzyskie, Góry Sowie, Masyw Ślęży, Wzgórza Strzegomskie), północno-zachodniej (Doliny Dolnej Odry i Warty) oraz północnej (Dolina Dolnej Wisły) i północno-wschodniej części kraju (MATUSZKIEWICZ 2008, MRÓZ i BĄBA 2010, CiEŚlAK 2015) (Ryc. 1).

Gatunki roślin przywiąane do siedlisk kserotermicznych to geograficznie i ekologicznie zróżnicowana grupa. Przyjmuje się, że na teren Polski dotarły trzema szlaka-

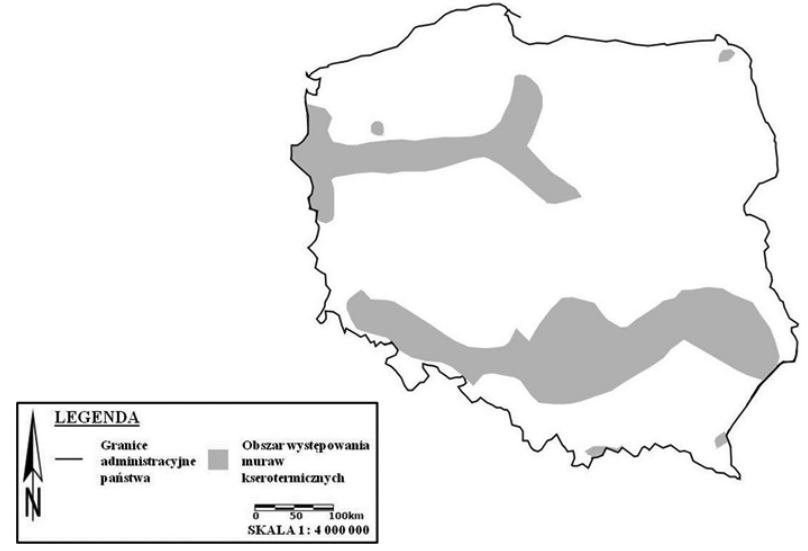

Ryc. 1. Rozmieszczenie muraw kserotermicznych na terenie Polski (wg MRÓz i BĄBA 2010).

mi migracyjnymi, w kilku falach od okresu postglacjalnego. Główny szlak migracji prowadził północnym grzbietem Karpat, $z$ Podola i Besarabii na Wyżynę Lubelska oraz Wyżynę Małopolska i dalej na północ kraju. Szlak morawski prowadził $z$ Niziny Wegierskiej poprzez Morawy i Bramę Morawska na Górny Ślask i Wyżynę Małopolska i dalej ku Północy wzdłuż Wisły i Warty (MEDWECKA-KORNAŚ i KORNAŚ 1977, SZAFER 1977).

Słowa kluczowe: czynna ochrona przyrody, edukacja ekologiczna, murawy kserotermiczne, sukcesja wtórna, zmiany w sposobie użytkowania gruntów 
Prawdopodobny szlak brandenbursko-pomorski prowadził natomiast $z$ Turyngii na Dolny Śląsk (Kostuch i MiszTal 2007). Osiedlanie się nowoprzybyłych taksonów i rozwój zbiorowisk kserotermicznych promowane były w późniejszym okresie przez odlesianie gruntów o żyznych, węglanowych glebach i gospodarkę rolno-pasterską, której początki na ziemiach polskich siegaja 5000 lat p.n.e. Najbardziej obfite występowanie siedlisk kserotermicznych na terenie Polski przypada na okres od XV w. do pierwszej połowy XX w. i zwiazane jest $z$ silnym rozwojem rolnictwa i hodowli zwierzat (BĄBA 2002/2003a, b, c; DZWONKO 2013; CIEŚlAK 2015). Trwajace od drugiej połowy $\mathrm{XX}$ w. przemiany socjoekonomiczne, intensyfikacja rolnictwa i zwiazane $z$ nia zmiany $w$ sposobie użytkowania gruntów, a także niedostateczna ochrona muraw kserotermicznych, przyczyniły się do uruchomienia procesów sukcesji wtórnej. W jej wyniku murawy uległy przekształceniu w kierunku ciepłolubnych zbiorowisk okrajkowych (Trifolio-Geranietea sanguinei), a następnie ciepłolubnych zbiorowisk zaroślowych (Rhamno-Prunetea). Końcowym stadium sukcesji były zbiorowiska leśne, takie jak gracd subkontynentalny (Tilio cordatae-Carpinetum betuli), kwaśna buczyna (Luzulo-Fagenion) i ciepłolubna buczyna storczykowa (Cephalanthero-Fagenion) (BĄBA 2002/2003a, GRABOWSKI 2010, BARAŃSKA 2014) (Ryc. 2).

$Z$ uwagi na znaczne bogactwo florystyczne oraz udział rzadkich i zagrożonych w skali Europy gatunków roślin naczyniowych, murawy kserotermiczne stanowia siedlisko przyrodnicze będace przedmiotem zainteresowania Wspólnoty Europejskiej, wymagające ochrony w formie wyznaczenia obszarów Natura 2000. Obecnie murawy kserotermiczne stanowią około 0,05\% łącznej powierzchni obszarów naturowych w Polsce. W typologii europejskiej sieci ekologicznej zbiorowiskom kserotermicznym odpowiada siedlisko przyrodnicze o kodzie 6210. Siedlisko o znaczeniu priorytetowym stanowia murawy, na których występuja cenne stanowiska storczykowatych (Orchidaceae). Z uwagi na zróżnicowanie składu gatunkowego, struktury zbiorowisk i uwarunkowania siedliskowe wyróżnić można murawy: naskalne (Seslerio-Festucion duriusculae, 6210-1), ostnicowe (Festuco-Stipion, 6210-2) i kwietne (Cirsio-Brachypodion pinnati, Mesobromion, 62103) (PERZANOWSKA i KuJAWA PAWLACZYK 2004, ROZPORZĄDZENIE 2010, BARAŃSKA i współaut. 2013). Wśród krajowych form ochrony obszarowej wymienić należy 34 rezerwaty stepowe o łącznej powierzchni 517 ha (GUS 2018). Wiele siedlisk murawowych chronionych jest także w formie użytków ekologicznych (BARAŃSKA 2014).

\section{ZAGROŻENIA MURAW KSEROTERMICZNYCH}

Transformacja rolnictwa europejskiego w II połowie $\mathrm{XX}$ w. (mechanizacja rolnictwa, wzrost znaczenia gospodarstw wielkoobszarowych z zamkniętymi pastwiskami o ustalonej

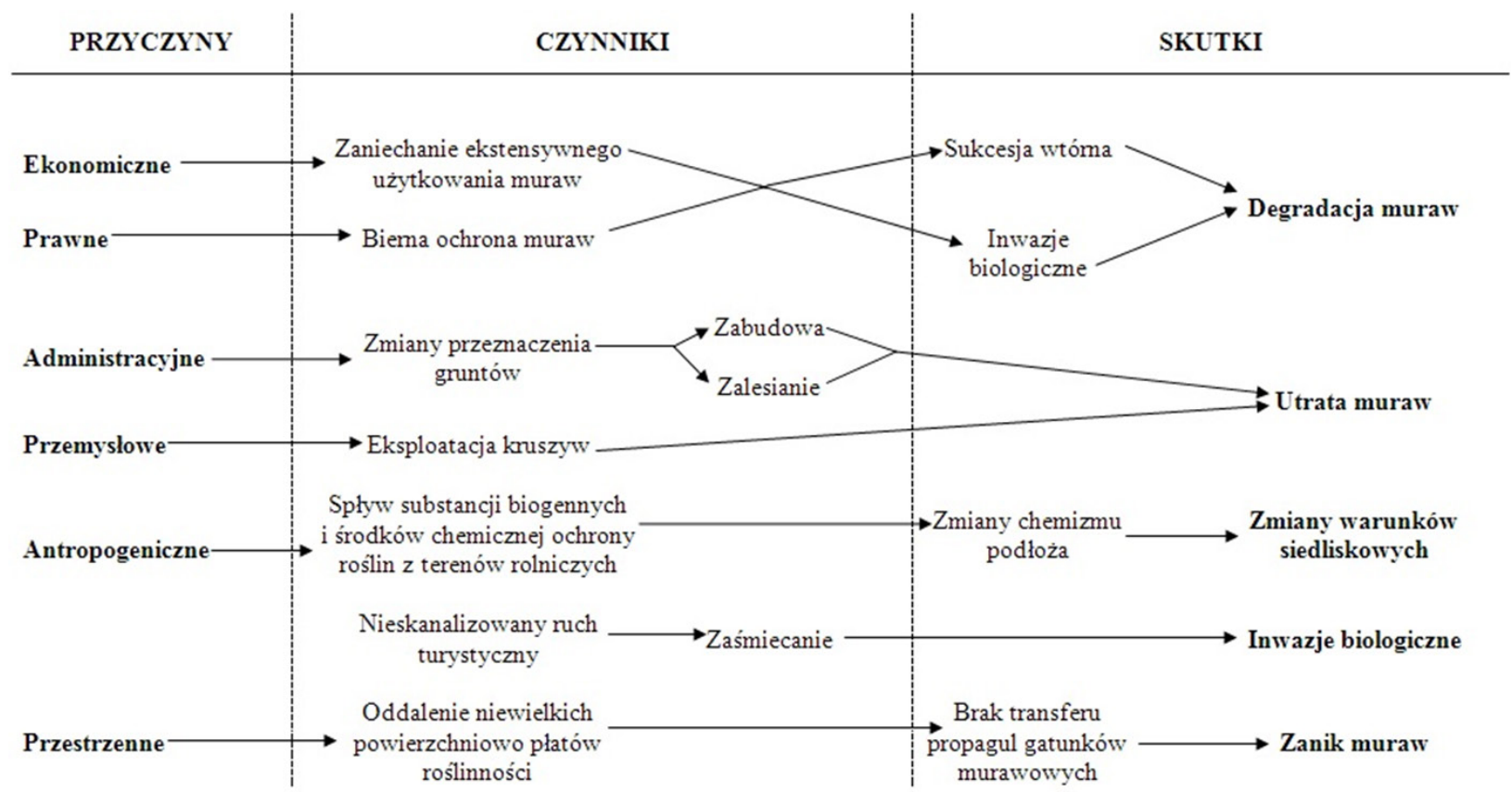

Ryc. 2. Główne grupy czynników stanowiących zagrożenie dla muraw kserotermicznych (wg PeRZANowSKA i KUJAWA-PAWLACZYK 2004; BARAŃSKA i współaut. 2010, 2013; MRÓZ i BĄBA 2010; CZYLOK i współaut. 2013; DZWONKO 2013; JAROSZ-SOSIK 2013; ROZWAŁKA 2013; BARAŃSKA 2014). 
obsadzie zwierzat) przyczyniły się do spadku ekonomicznej opłacalności tradycyjnych metod gospodarowania (BĄBA 2002/2003a, CZYLOK $\mathrm{i}$ współaut. 2013, DzwONKO 2013). Zaprzestanie ekstensywnej gospodarki pasterskiej spowodowało odkładanie się znacznej warstwy materii organicznej i wzrost żyzności podłoża. Zainicjowany został proces sukcesji wtórnej, prowadzacy do przekształcenia muraw kserotermicznych w ciepłolubne okrajki z klasy Trifolio-Geranietea sanguinei, a następnie w ciepłolubne zarośla (Rhamno-Prunetea) z udziałem berberysu zwyczajnego (Berberis vulgaris), głogu jednoszyjkowego (Crataegus monogyna), szakłaka pospolitego (Rhamnus catharticus) i róż (Rosa sp.). Końcowym stadium sukcesji jest powstanie zbiorowiska leśnego, reprezentowanego przez grąd subkontynentalny (Tilio cordatae-Carpinetum betuli) oraz kwaśne (Luzulo-Fagenion) lub ciepłolubne buczyny storczykowe (Cephalanthero-Fagenion) (MICHALIK 1974, MEDWECKA-KORNAŚ i KORNAŚ 1977, PERZANOWSKA i KUJAWA-PAWLACZYK 2004, GRABOWSKI 2010, BARAŃSKA 2014) (Ryc. 2).

Wiele cennych siedlisk kserotermicznych zostało utraconych w wyniku zmian w sposobie użytkowania gruntów: zalesienia, zabudowy, przekształcenia gruntów w pola uprawne lub intensywnie użytkowane pastwiska, czy eksploatację kruszyw (m. in. gliny, kredy, piasku, kredy). Spływajace $\mathrm{z}$ pól substancje biogenne zawarte $\mathrm{w}$ nawozach mineralnych sa odpowiedzialne za eutrofizację podłoża leżących w pobliżu muraw, zaś odcieki niosace pozostałości środków chemicznej ochrony roślin przyczyniaja się do spadku zawartości węglanu wapnia w glebie i w konsekwencji jej zakwaszenia. Kolejnym $z$ czynników wywierających negatywny wplyw na siedliska kserotermiczne jest nadmierny ruch turystyczny. Presja turystyczna prowadzi do mechanicznego uszkodzenia roślinności. Pozostawione przez turystów odpady stanowia często droge do rozprzestrzeniania się diaspor inwazyjnych gatunków roślin obcego pochodzenia (PERZANOWSKA i KUJAWA-PAWLACZYK 2004, MRÓZ i BABA 2010, CZYLOK i współaut. 2013, RozWAEKA 2013, BARAŃSKA 2014).

W następstwie silnych przekształceń warunków abiotycznych, murawy kserotermiczne kolonizowane sa przez ekspansywne gatunki rodzime, takie jak m.in. rajgras wyniosły (Arrhenatherum elatius), kłosownica pierzasta (Brachypodium pinnatum), trzcinnik piaskowy (Calamagrostis epigejos) i malina właściwa (Rubus idaeus), a także inwazyjne taksony roślin obcego pochodzenia. Ekspansywne gatunki traw wypieraja gatunki muraw na drodze konkurencji, prowadzac do powstawania trwałych, niemal jednogatunko- wych zbiorowisk (BABA i współaut. 2012a, b, 2016). W zaroślach często spotyka się robinię akacjowa (Robinia pseudacacia). Jest ona gatunkiem o wzroście klonalnym i silnych właściwościach regeneracyjnych. Tworzy silne odrosty $z$ pni i niewielkich fragmentów korzeni oraz wytwarza znaczna ilość nasion. Charakteryzuje się również zdolnością do symbiotycznego wiazania azotu atmosferycznego i wytwarzania związków allelopatycznych. Do innych odnotowywanych gatunków inwazyjnych należą barszcz Sosnowskiego (Heracleum sosnowskyi) oraz nawłoć kanadyjska (Solidago canadensis) (RAHMONOV i PARUSEL 2012, TOKARSKA-GUZIK i współaut. 2012, ZAJACZKOWSKI i WOJDA 2012, CZYLOK i współaut. 2013, BARAŃSKA i współaut. 2013, ROZWAEKA 2013, BARAŃSKA 2014) (Ryc. 3).

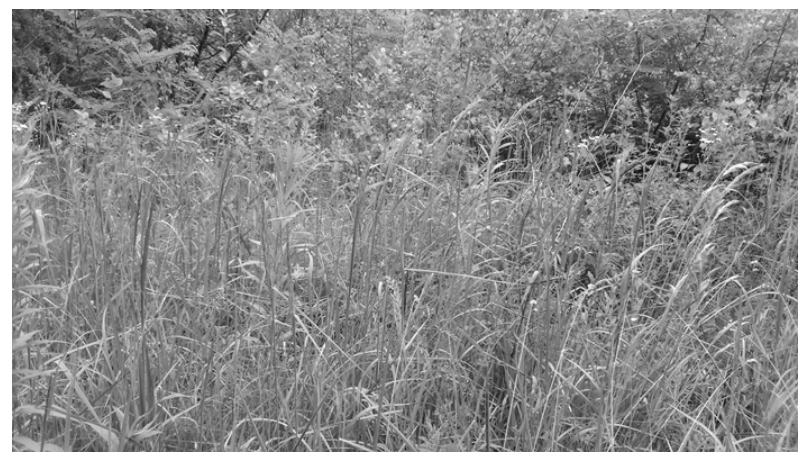

Ryc. 3. Ekspansja trzcinnika piaskowego na nieużytkowanej murawie kserotermicznej w Jaworznie. W tle zarośla robinii akacjowej.

Obserwacje intensywnie użytkowanych muraw kserotermicznych $z$ początków $X X \mathrm{w}$. skutkowały przeświadczeniem o negatywnym wpływie jakichkolwiek form gospodarowania człowieka na murawy. Zastosowanie ochrony biernej w powoływanych do życia w połowie XX w. rezerwatach roślinności nieleśnej, przyniosło skutek odwrotny od oczekiwanego, przyczyniajac się do uruchomienia procesów sukcesji wtórnej oraz utraty cennych i rzadkich gatunków, dla ochrony których rezerwaty zostały ustanowione (BARAŃSKA i współaut. 2010, CZYLOK i współaut. 2013, BARAŃSKA 2014) (Ryc. 2).

W konsekwencji zmian, jakie zaszły w rolnictwie i niewłaściwie zaplanowanej ochrony, murawy kserotermiczne stały się jednymi $\mathrm{z}$ najbardziej zagrożonych siedlisk przyrodniczych w Europie (BARAŃSKA i współaut. 2013). Wraz $z$ postępującym wzrostem fragmentacji i izolacji niewielkich powierzchniowo płatów zbiorowisk murawowych, migracja propagul gatunków kserotermicznych stała się niemożliwa lub znacznie utrudniona (DZWONKO 2013, JAROSZ-SOSIK 2013, RoZWAEKA 2013) (Ryc. 2). W samej tylko zachod- 
niej Polsce na przestrzeni ostatnich 30 lat $z$ powyższych przyczyn powierzchnia dobrze zachowanych muraw zmniejszyła się o około $70 \%$. Szacuje się, że jeśli obecny trend nie zostanie zahamowany w ciagu najbliższych kilkunastu lat utraconych zostanie ponad $80 \%$ obecnie istniejacych siedlisk kserotermicznych (BARAŃSKA i współaut. 2010) (Ryc. 4).

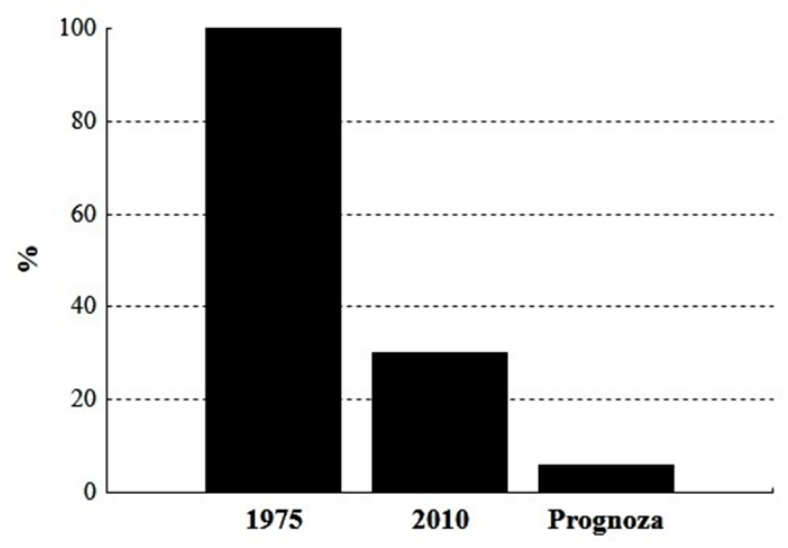

Ryc. 4. Zmiany powierzchni siedlisk kserotermicznych w zachodniej Polsce w latach 1975-2010 oraz prognoza dotyczaca powierzchni siedliska przy braku odpowiednich zabiegów ochronnych (wg BARAŃSKA i współaut. 2010, zmieniona).

\section{OCHRONA MURAW \\ KSEROTERMICZNYCH W POLSCE}

Od końca lat 60. XX w. prowadzone były obserwacje nad dynamika i długotrwałymi przemianami roślinności murawowej w wyniku zaprzestania wypasu (MicHALIK 1990, KAŹMIERCZAKOWA 1991, DZWONKO i LOSTER 2008). Przykładem przeprowadzonego $z$ sukcesem programu ochrony muraw kserotermicznych jest Ojcowski Park Narodowy. Już w latach 80. XX w. podjęto tu pierwsze próby ochrony muraw poprzez eksperymentalne usuwanie drzew i krzewów. W oparciu o wieloletnie badania, powstał kompleksowy, bo uwzględniajacy kształtowanie układu przestrzennego i wzajemnych powiazań płatów, program ochrony tych zbiorowisk. Z ochrona muraw Ojcowskiego Parku Narodowego ściśle powiazany jest program monitoringu, majacy na celu określenie wpływu zastosowanych zabiegów na strukturę i dynamike muraw kserotermicznych oraz ich ewentualna weryfikację (MICHALIK 1993; BĄBA 2002/2003a, b, c). Obecnie niemal wszystkie płaty muraw kserotermicznej w Dolinie Pradnika sa poddawane systematycznemu odkrzaczaniu co 1-2 lata oraz wypasowi, stanowiąc jeden $z$ najdłużej trwają- cych programów ochrony aktywnej w Polsce (BABA 1999). W ostatnich latach podjęto w Polsce szereg projektów, mających na celu ochronę muraw kserotermicznych m.in. Wyżyny Krakowsko-Częstochowskiej, Wyżyny Miechowskiej, Niecki Nidziańskiej, Dolnej Odry i Lubelszczyzny. Zastosowano różnorodne zabiegi: od odkrzaczania, kombinacji odkrzaczania i późniejszego usuwania odrośli lub wypasu, do samego wypasu (BĄBA 2002/2003b, c; CZYLOK i współaut. 2013; GAWROŃSKI 2013; BARAŃSKA 2014).

\section{INWENTARYZACJA PRZYRODNICZA}

Właściwe zaplanowanie zabiegów ochrony czynnej wymaga zapoznania się $z$ dostępnymi danymi literaturowymi, wynikami badań historycznych oraz przeprowadzenia szczegółowej inwentaryzacji przyrodniczej obszaru przewidzianego do objeccia ochrona (KoRDOWSKA 2015). Podejmowane działania powinny wywierać presję na roślinność zbliżona do tradycyjnych ekstensywnych metod gospodarowania (DzwONKo 2013).

Inwentaryzacja przyrodnicza pozwala na ocenę wartości przyrodniczej i stanu zachowania siedliska oraz na ustalenie zakresu i kosztorysu projektowanych zabiegów ochrony czynnej. Przed przystapieniem do inwentaryzacji na podstawie dostepnych materiałów określa się strukturę własnościowa obiektu. W przypadku, gdy murawa stanowi własność prywatną, należy podjąć rozmowy $z$ właścicielem terenu w celu ustalenia, czy wyraża on zgodę na przeprowadzenie planowanych działań ochronnych i czy będzie aktywnie w nich uczestniczył. Wobec braku zainteresowania właściciela obiektu zasadne jest podjęcie próby nabycia nieruchomości, na których zlokalizowane sa cenne płaty roślinności kserotermicznej. Konieczne jest również zaznajomienie się $z$ Miejscowymi Planami Zagospodarowania Przestrzennego. Pozwala to na podjęcie odpowiednio wcześniej działań zaradczych przewidzianych w ustawach: o ochronie przyrody, o zapobieganiu szkodom w środowisku i ich naprawie, o udziale społeczeństwa w ochronie środowiska, a także udostępniania informacji o środowisku, w sytuacji, gdy teren murawy przewidziany jest pod realizację np. inwestycji drogowej, mieszkaniowej, rekreacyjnej, usługowej, etc. Jeśli natomiast interesująca nas murawa objęta jest jedna $z$ form ochrony obszarowej wymienionych w ustawie, należy o tym fakcie, jeszcze przed podjęciem jakichkolwiek działań, powiadomić organ sprawujący nadzór nad obszarem i uzyskać stosowne zezwolenia. Studium nad wynikami badań historycznych może z kolei dostarczyć cennych informacji, które w dalszym etapie 


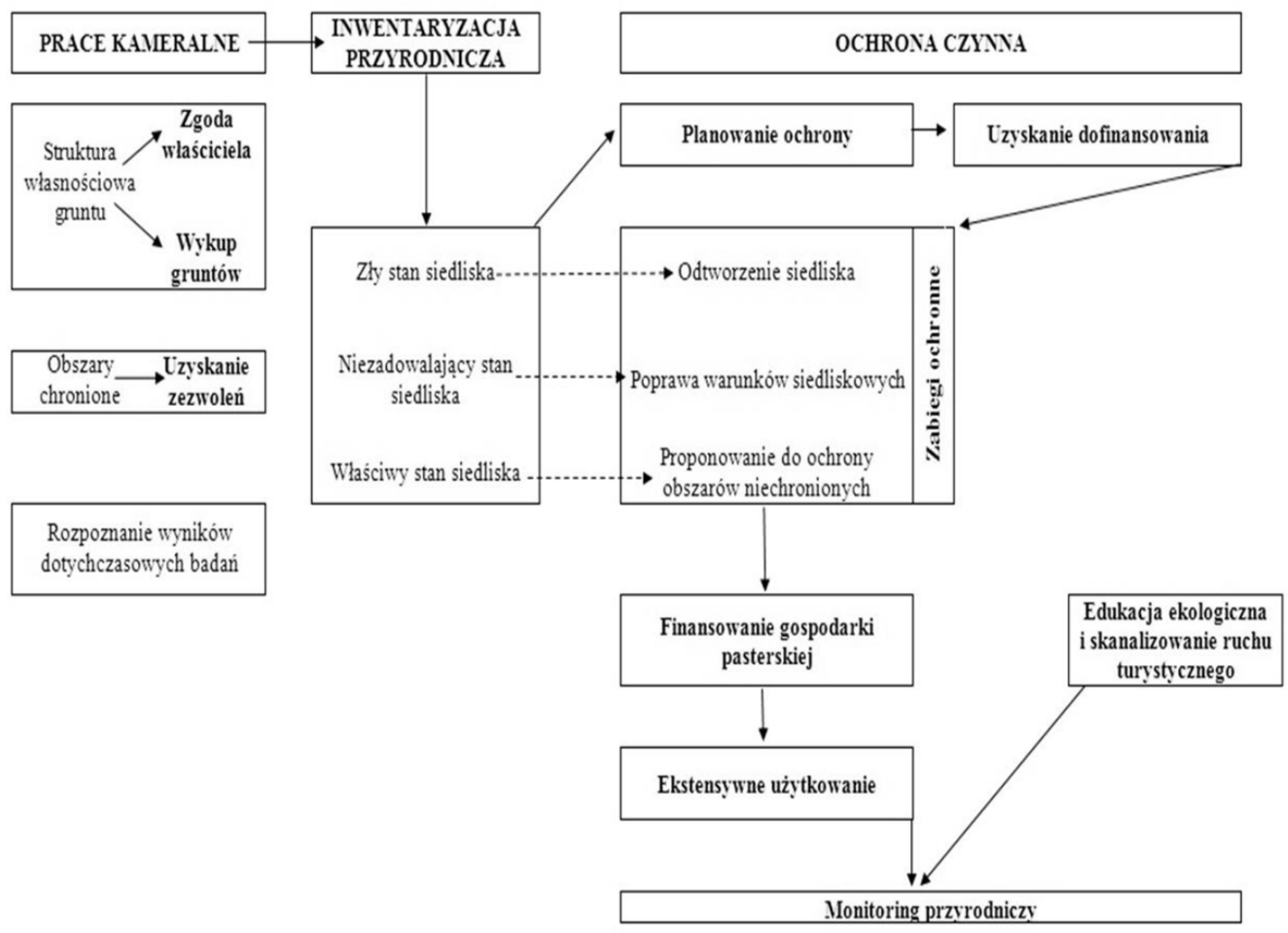

Ryc. 5. Procedura postępowania przy planowaniu i prowadzeniu czynnej ochrony muraw kserotermicznych (wg (wg UsTAWA 2004, 2007, 2008; BARAŃSKA i współaut. 2010, 2013; MRÓZ i BABA 2010; BARAŃSKA 2013; JAROSZ-SOSIK 2013; BARAŃSKA 2014; KORDOWSKA 2015; KULIK i współaut. 2015).

pracy umożliwia prześledzenie tendencji dynamicznych roślinności (UsTAWA 2004, 2007, 2008; BARAŃSKA i współaut. 2010, 2013; KORDOWSKA 2015) (Ryc. 5).

Inwentaryzacja przyrodnicza powinna być prowadzona zgodnie $z$ metodyka przedstawiona w przewodnikach metodycznych monitoringu siedlisk przyrodniczych. Badania fitosocjologiczne należy wykonać w okresie od maja do połowy sierpnia, gdy większość gatunków murawowych znajduje się w optimum kwitnienia. Ocena stanu zachowania i zagrożeń siedlisk roślinności kserotermicznej dokonywana jest w oparciu o specyficzne wskaźniki struktury i funkcji siedliska przyrodniczego (gatunki charakterystyczne, obce gatunki inwazyjne, rodzime gatunki ekspansywne roślin zielnych, ekspansja krzewów i podrostu drzew, liczba gatunków storczykowatych, zachowanie strefy ekotonowej) oraz parametr „perspektywy ochrony”. Stosuje się tutaj trzystopniowa skalę: FV - stan właściwy, U1 - stan niezadowalajacy i U2 - stan zły (MRÓz i BĄBA 2010) (Ryc. 5). Murawy kserotermiczne odznaczaja się niezwykłym bogactwem fauny bezkręgowej. Jako przykład można podać wysokie średnie zagęszczenie przedstawicieli pszczół (Apoidea) na poziomie 805 osobników/ha w przypadku muraw Ko- tliny Toruńskiej czy 1229 osobników/ha w przypadku siedlisk kserotermicznych doliny Dolnej Wisły (BANASZAK i współaut. 2000). Ponadto $z$ uwagi na znaczną mozaikowatość siedlisk kserotermicznych murawy są często swoistymi „wyspami”, skupiajacymi miejsca lęgowe lub żerowiska cennych gatunków ptaków, jak wymieniona w załączniku I Dyrektywy Ptasiej dzierzba czarnoczelna (Lanius minor) (DYREKTYWA 2009, ROZWAEKA 2013). Stąd przy planowaniu zakresu i czasu wykonania działań ochronnych należy uwzględnić także wyniki inwentaryzacji faunistycznej (MAZUR i KUBISZ 2000).

Wyniki badań umożliwią stworzenie dokumentacji przyrodniczej, która będzie stanowić podstawę merytoryczną do objęcia murawy jedna $z$ obszarowych form ochrony przewidzianych ustawa o ochronie przyrody. Należy ją przekazać do właściwych miejscowo rad gmin i Regionalnych Dyrekcji Ochrony Środowiska (USTAWA 2004, BARAŃSKA i współaut. 2013, BARAŃSKA 2014) (Ryc. 5). Intensywne działania majace na celu ochronę fitocenoz murawowych prowadzone sa m.in. w Krakowie, gdzie od 2016 r. zabiega się o utworzenie 7 nowych użytków ekologicznych chroniących roślinność kserotermiczną (MYDŁOWSKI 2016). 
Istnieje możliwość wsparcia finansowego planowanych prac ze środków krajowych (Narodowy Funduszu Ochrony Środowiska i Gospodarki Wodnej, właściwe miejscowo Wojewódzkie Fundusze Ochrony Środowiska, Fundacja EkoFundusz) i unijnych (Europejski Fundusz Rozwoju Regionalnego w ramach Programu Operacyjnego Infrastruktura i Środowisko, Europejski Fundusz Rolny na rzecz Rozwoju Obszarów Wiejskich, Instrument Finansowania Komisji Europejskiej LIFE, Mechanizm Finansowy Europejskiego Obszaru Gospodarczego, Norweski Mechanizm Finansowy) (BARAŃSKA i współaut. 2010, JAROSZ-SOSIK 2013, BARAŃSKA 2014, KORDOWSKA 2015, KULIK i współaut. 2015) (Ryc. 5)

\section{ODTWARZANIE MURAW KSEROTERMICZNYCH}

Kierunki zabiegów ochrony czynnej uzależnione sa od stanu zachowania, stopnia degradacji i głównych zagrożeń badanych płatów roślinności kserotermicznej (KORDOWSKA 2015). W przypadku złego stanu siedliska (U2), gdy ponad 5\% powierzchni murawy pokrywaja gatunki inwazyjne, tworzace zwarte płaty, a pokrycie ekspansywnych taksonów drzew i krzewów, tworzacych zwarte zarośla przekracza 25\%, podejmuje się działania odtwórcze (MRÓz i BĄBA 2010) (Ryc. 5). Pierwszy (techniczny) etap prac obejmuje wycięcie lub wyrwanie $z$ korzeniami ekspansywnych i inwazyjnych roślin (np. robinii akacjowej), a nastepnie zdarcie wierzchniej warstwy podłoża do głębokości $40 \mathrm{~cm}$. Pozwala to na poprawę warunków troficznych gleby, poprzez ograniczenie ilości azotu i zwiększenie dostępności węglanu wapnia. $Z$ kolei zniszczenie banku nasion oraz kłaczy i korzeni niepożądanych gatunków znacznie ogranicza ryzyko ich odtwarzania się, wskutek odbijania pędów z szyi korzeniowej. W kolejnym (biologicznym) etapie dokonuje się reintrodukcji gatunków murawowych poprzez wysiew nasion, rozkładanie siana lub „transplantację" darni. Niezwykle istotnym jest, by wprowadzony material roślinny pochodził $z$ lokalnej puli genowej, a więc $z$ dobrze zachowanych płatów roślinności kserotermicznej, położonych w możliwie najbliższym sąsiedztwie odtwarzanej murawy (PERZANOWSKA i KUJAWA-PAWLACZYK 2004, BARAŃSKA 2013, BARAŃSKA i współaut. 2013).

\section{ELIMINACJA EKSPANSYWNYCH I} INWAZYJNYCH GATUNKÓW ROSLIN

W sytuacji, gdy stan siedliska jest niezadowalajacy (U1), czyli gdy pokrycie roślin inwazyjnych nie przekracza $5 \%$ i nie tworza one zwartych płatów, zaś pokrycie eks- pansywnych gatunków drzew i krzewów wynosi $10-25 \%$ i nie tworza one zwartych zarośli, podejmowane działania maja charakter zapobiegawczy (MRÓz i BĄBA 2010). Prace te obejmuja głównie zabiegi mechaniczne, skoncentrowane na usunięciu ekspansywnych zarośli drzew i krzewów oraz gatunków inwazyjnych (KoRDOwSKA 2015). Pozwala to na przywrócenie właściwych warunków świetlnych i termicznych roślinności kserotermicznej oraz zapobieżenie inwazjom biologicznym (Ryc. 5). Należy przy tym pamiętać, że wycinka drzew i krzewów powinna być prowadzona w okresie jesienno-zimowym (od października do marca), tak by uniknąć ewentualnej utraty cennych gatunków entomo- i ornitofauny (BARAN̂SKA 2013). W przypadku niezwykle ekspansywnych gatunków takich, jak m.in. robinia akacjowa czy śliwa tarnina, silnie rozrastajacych się z szyi korzeniowej, koniecznym może okazać się zastosowanie odpowiednich środków chemicznych, stosowanych na pęd główny (BĄBA 2002/2003c, PERZANOWSKA i KuJAWA-PAWLACZYK 2004). Skutecznym rozwiazaniem może być także przykrycie ekspansywnych odrostów drzew i krzewów czarną folią, co skutkuje ich obumarciem wskutek braku dopływu światła (BARAŃsKA 2014). Dobór skutecznej techniki (biologicznej, chemicznej, mechanicznej lub mieszanej) eliminacji gatunków inwazyjnych wymaga dobrej znajomości biologii gatunku (TOKARSKA-GUZIK 2009). Skuteczna metoda zwalczania gatunków anemochorycznych, takich jak nawłoć kanadyjska i późna (Solidago canadensis, S. gigantea) jest regularne koszenie, prowadzone minimum dwukrotnie w ciagu roku (w maju i kwietniu) (TOKARSKA-GUZIK i współaut. 2015a, KOPEĆ i MiCHALSKA-HEJDUK 2016). W eliminacji gatunków rozmnażajacych się generatywnie i wytwarzajacych znaczna liczbe propagul, jak barszcz Mantegazziego (Heracleum mantegazzianum, do 50.000 owocków na 1 osobnika) czy barszcz Sosnowskiego (Heracleum sosnowskyi, do 20.000 owocków na 1 osobnika) dobre efekty można uzyskać ścinając łodygi przed wydaniem nasion, jak najniżej, by zapobiec powstaniu pędu kwiatowego. W ten sposób diaspory nie przedostaja się do podłoża i tym samym przerwany zostaje cykl życiowy roślin (NIELSEN i współaut. 2005, PERGLOVÁ i współaut. 2007, KRZYSZTOFIAK 2009, SACHAJDAKIEWICZ i współaut. 2014). W przypadku taksonów rozmnażających się wegetatywnie przez rozrost i fragmentację kłaczy, o znacznych zdolnościach do regeneracji, za najbardziej skuteczne uważa się metody kombinowane (TOKARSKA-GUZIK i współaut. 2015b). Po spryskaniu pędów herbicydem lub wprowadzeniu herbicydów do łodyg, przeprowa- 
dza się cykliczna wycinkę (4-8 razy w ciągu sezonu wegetacyjnego). Alternatywna metoda jest przeprowadzenie wycinki wiosna, a następnie stosowanie oprysków lub iniekcji w okresie letnim (McHuGH 2006).

\section{USUWANIE NADMIARU BIOMASY}

W przypadku dobrze zachowanych fitocenoz murawowych (FV), wolnych od gatunków inwazyjnych, obok eliminacji ekspansywnych gatunków drzew i krzewów, istotnym działaniem zaradczym niedopuszczenie do nadmiernego wzbogacenia podłoża w materię organiczną (MRÓZ i BĄBA 2010, BARAŃSKA i współaut. 2013). Gromadzenie się martwych szczątków roślinnych (tzw. wojłoku) może powodować wzrost zacienienia podłoża, hamując kiełkowanie i wzrost światłolubnych gatunków murawowych i tym samym inicjować procesy sukcesyjne. Dlatego też nadmiar biomasy powinien być usuwany (BARAŃSKA 2014).

\section{EKSTENSYWNE UŻYTKOWANIE MURAW KSEROTERMICZNYCH}

Warunkiem koniecznym przetrwania muraw kserotermicznych jest powrót do tradycyjnych, ekstensywnych form użytkowania rolniczego $z$ udziałem lokalnej społeczności (GRABOWSKI 2011) (Ryc. 5). Zwierzęta powinny pochodzić $z$ ras rodzimych, które charakteryzuja się lepszym przystosowaniem do lokalnych warunków środowiska i wyższą odpornością na choroby. Przykładowo owca rasy olkuskiej $z$ rejonu Jury Krakowsko-Częstochowskiej jest jedyną rodzima rasa odtworzona po wyginięciu. Owca olkuska cechuje się dobrze rozwiniętym instynktem macierzyńskim i wysoka plennościa, która przy zapewnieniu odpowiednich warunków żywieniowych wynosi 235-400\% (SOSIN-BZDUCHA i współaut. 2012, KORCZYŃSKI 2013). Dobrym rozwiazaniem, pozwalającym w pełni wykorzystać zaletę selektywnego zgryzania roślinności przez zwierzęta, jest stosowanie mieszanych stad owiec i kóz. Te pierwsze preferuja rośliny miękkolistne, eliminujac ekspansywne gatunki lakowe i ruderalne, natomiast kozy zgryzaja odrosty uprzednio usuniętych ekspansywnych drzew i krzewów, ograniczajac ich rozprzestrzenianie się. Dodatkowo, zwierzęta w trakcie wypasu ugniataja powierzchnię muraw, niszczac warstwę wojłoku i zwiększając tym samym dostępność światła, a także uruchamiajac bank nasion w glebie, co przyśpiesza rozprzestrzenianie się i rozwój gatunków murawowych (BĄBA i KOMPAŁA-BĄBA 2005, CZARNECKA 2008, BANACH 2010, BARAŃSKA i współaut. 2013, KORCZYŃSKI 2013, BARAŃSKA
2014, JANICKA i JANICKA 2015). W przypadku niewielkich, izolowanych płatów roślinności kserotermicznej, gdzie prowadzenie tradycyjnego wypasu jest znaczaco utrudnione lub niemożliwe, zastosowanie znajduje metoda wypasu obwoźnego, co znaczaco ułatwia dyspersje nasion pomiędzy płatami muraw (Ryc. 6).

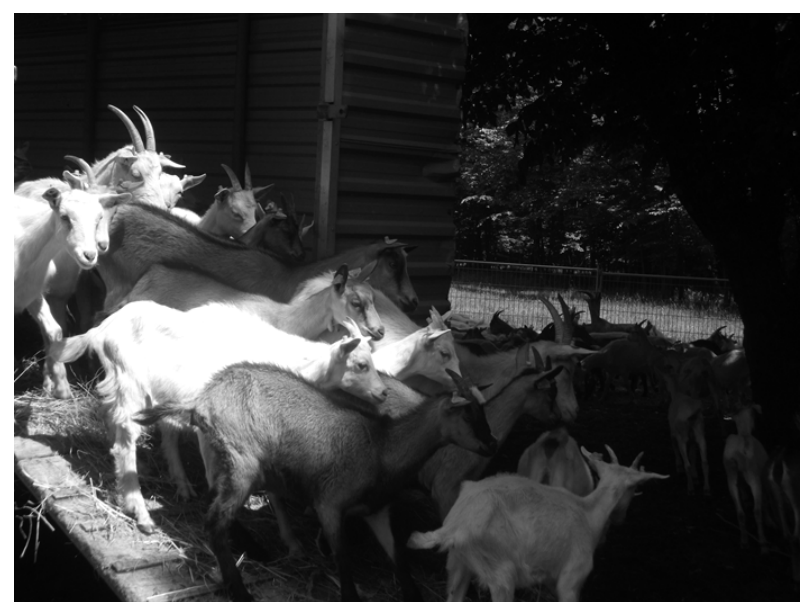

Ryc. 6. Wypas obwoźny na terenie Jury Krakowsko-Częstochowskiej.

Powierzchnie o wielkości około 1 ha, wygrodzone za pomoca elektrycznego pastucha, wypasane sa przez okres 1-2 tygodni $\mathrm{w}$ ciagu sezonu wegetacyjnego (od kwietnia do października). Na każdej murawie ustawiana jest drewniana wiata, a zwierzęta znajduja się pod całodobowym nadzorem. W celu ułatwienia transferu diaspor gatunków murawowych do siedlisk zdegenerowanych, w pierwszej kolejności wypasa się najlepiej zachowane stanowiska (BANACH 2010, BARAŃSKA 2013, BARAŃSKA i współaut. 2013). Fakt ten znajduje potwierdzenie w wynikach badań przeprowadzonych na nawapiennych murawach w południowo-zachodnich Niemczech. Nasiona były przenoszone na drodze epi- lub endozochorii. W badaniach wykazano, że jedna owca przenosiła średnio na runie około 8500 nasion, należących do 85 taksonów roślin, zaś 380 nasion należących do 47 gatunków przenoszonych było w układzie pokarmowym. W oparciu o powyższe wyniki oszacowano, iż w ciagu jednego sezonu wegetacyjnego stado liczace 400 owiec może stanowić wektor migracji ponad 8 milionów diaspor (FISCHER i współaut. 1996, Poschlod i Bonn 1998). Niezależnie od zastosowanej metody użytkowania obsada zwierzat nie powinna przekraczać 0,5 DJP/ha (5 sztuk zwierzat/ha). Zaleca się również pozostawienie fragmentów (około $20 \%$ ) niezgryzionej murawy, corocznie w 
innym miejscu (BARAŃSKA i współaut. 2013, BARAŃSKA 2014).

Mechanizmem mającym na celu zachęcenie właścicieli obszarów, na których znajdują się cenne zbiorowiska roślinności kserotermicznej do ich ekstensywnego użytkowania sa dopłaty ze środków przewidzianych w ramach działania 10. (działanie rolno-środowiskowo-klimatyczne) Programu Rozwoju Obszarów Wiejskich na lata 2014-2020, które finansowane jest przez Europejski Fundusz Rolny na rzecz Rozwoju Obszarów Wiejskich (AGENCJA 2016a, b) (Ryc. 5). W przypadku, gdy murawa położona jest na obszarze Specjalnej Ochrony Ptaków, posiadacz terenu może wnioskować o dopłatę w ramach wariantu 4.3. programu rolno-środowiskowego. Natomiast dla muraw położonych poza obszarami Natura 2000 można ubiegać się o dofinansowanie w ramach pakietu 5.3. W obu przypadkach kwota dopłaty uzależniona jest od wielkości gospodarstwa i wynosi $1300 \mathrm{zl} /$ ha dla gospodarstw o powierzchni do 50 ha. Stawka dla gospodarstwa o powierzchni 50-100 ha wynosi $75 \%$, zaś powyżej 100 ha - 60\% kwoty podstawowej (AGENCJA 2016c). Hodowcy rodzimych ras zwierzat gospodarskich zagrożonych wyginięciem moga się $z$ kolei ubiegać o wsparcie $w$ ramach pakietu 7. -zachowanie zagrożonych zasobów genetycznych zwierzat w rolnictwie. Dopłaty przyznawane sa do samic lokalnych ras zwierzat i wynosza w przypadku owiec 360 zł/szt., a kóz - 580 zł/szt. (AGENCJA 2016 d).

\section{DYSKUSYJNE METODY OCHRONY CZYNNEJ}

W podręcznikach metodycznych oraz zaleceniach ochronnych dla typów siedlisk przyrodniczych wydanych przez Ministerstwo Środowiska i Główna Inspekcję Ochrony Środowiska wśród metod ochrony czynnej muraw kserotermicznych obok ekstensywnego wypasu proponowane jest użytkowanie kośne (GŁÓWNY INSPEKTORAT OCHRONY ŚRODOWISKA 2019, PERZANOWSKA i KUJAWA-PAWLACZYK 2004, MRÓZ i BĄBA 2010). Tymczasem liczne doniesienia literaturowe wskazuja, że pokos nie zapewnia prawidłowego kształtowania zbiorowisk roślinności kserotermicznej (KULIK i współaut. 2015). Z obserwacji BARAŃSKIEJ i współaut. (2013) oraz JANICKIEJ i JANICKIEJ (2015) wynika, iż koszenie promuje rozwój ekspansywnych gatunków traw, takich jak np. rajgras wyniosły (Arrhenatherum elatius), kłosownica pierzasta (Brachypodium pinnatum), czy trzcinnik piaskowy (Calamagrostis epigejos), co skutkuje wypieraniem taksonów murawowych i zubożeniem gatunkowym zbiorowisk roślinności kserotermicznej.

Metoda kontrowersyjna, zakazana w polskim ustawodawstwie, jest kontrolowane wypalanie muraw (MAZUR i KUBISZ 2000, USTAWA 2004). Wśród zalet wczesnowiosennego wypalania wymienia się zahamowanie sukcesji ekspansywnych drzew i krzewów oraz usunięcie nadmiaru biomasy (ZARZYCKI i SZYMACHA 2006). Jednakże ogień stanowi poważne zagrożenie dla fauny związanej $z$ siedliskami kserotermicznymi (RATYŃSKA i WALDON 2011, JASTRZEBBSKA 2013). Pożary eliminuja również taksony roślin wrażliwe na wysoka temperature, w tym cenne elementy flory kserotermicznej jak np. wymienionego w Polskiej Czerwonej Księdze Roślin żmijowca czerwonego (Echium russicum) (KUCHARZYK 2010, CHMIELEWSKI i współaut. 2014). Wypalanie suchej masy sprzyja również rozprzestrzenianiu się ekspansywnych geofitów, bardziej odpornych na oddziaływanie wysokiej temperatury, takich jak perz właściwy (Agropyron repens), trzcinnik piaskowy (Calamagrostis epigejos), ostrożeń polny (Cirsium arvense) czy inwazyjne gatunki nawłoci (Solidago canadensis i $S$. gigantea), co wpływa na zmniejszenie różnorodności florystycznej zbiorowisk murawowych (SzCZEŚSNIAK i KĄCKI 2004, DZIURA i WOLAŃSKI 2013, TRĄBA 2014, JANICKA i JANICKA 2015).

\section{MONITORING PRZYRODNICZY}

Ocena tempa regeneracji muraw kserotermicznych oraz zachodzacych na nich procesów pozwala na weryfikację skuteczności dotychczasowych działań ochrony czynnej oraz na ich modyfikację $\mathrm{w}$ razie konieczności (BANACH 2010, BARAŃSKA i współaut. 2013) (Ryc. 5). Metodyka badań jest analogiczna jak podczas pierwszej inwentaryzacji florystycznej, a ich częstotliwości powinna być uzależniona od tempa przemian dynamicznych roślinności. W początkowym okresie wskazane jest prowadzenie badań corocznie. Wraz $z$ ustabilizowaniem się składu florystycznego można zmniejszyć częstotliwość obserwacji. Wówczas monitoring powinien być powtarzany co 5-6 lat (MRÓz i BĄBA 2010, KORDOWSKA 2015).

\section{EDUKACJA EKOLOGICZNA I SKANALIZOWANIE RUCHU TURYSTYCZNEGO}

Przemyślana organizacja turyzmu pozwala ograniczyć ryzyko zaśmiecania muraw i mechanicznego niszczenia roślinności przez amatorów wspinaczki skałkowej (KRYŚciŃSKA i współaut. 2011, KULIK i współaut. 2015). Nowoczesna dydaktyka, podkreślająca zna- 
czenie różnorodności biologicznej siedlisk kserotermicznych, realizowana za pośrednictwem środków masowego przekazu, szkoleń, czy publikacji materiałów informacyjnych pozwala podnieść świadomość ekologiczna społeczeństwa. Reorganizacja istniejących szlaków turystycznych, odpowiednio wytyczone ścieżki dydaktyczne wraz $z$ tablicami informującymi turystów o walorach muraw kserotermicznych i znaczeniu ich ochrony, właściwa lokalizacja elementów małej architektury - miejsc widokowych, wiat dla turystów czy koszy na śmieci pozwola skanalizować ruch turystyczny, odciagajacc uwage turystów od najcenniejszych płatów roślinności kserotermicznych (BARAŃsKA i współaut. 2013, KoRDOWSKA 2015) (Ryc. 5).

\section{DOBRE PRAKTYKI - PROGRAM "OWCA PLUS"}

Przykładem dobrych praktyk $z$ zakresu aktywnej ochrony przyrody jest realizowany od 2007 r. przez Samorzą Województwa Śląskiego Program Aktywizacji Gospodarczej oraz Zachowania Dziedzictwa Kulturowego Beskidów i Jury Krakowsko-Częstochowskiej „Owca Plus” (SoBAla 2014). Sukces programu nie byłby możliwy bez należycie przeprowadzonego dialogu społecznego. Działania informacyjne uświadamiajace znaczenie miejscowych rolników w ochronie cennych przyrodniczo siedlisk dały poczatek owocnej współpracy między lokalnymi społecznościami a środowiskami zwiazanymi $z$ ochrona przyrody (CZYLOK i współaut. 2013, KOMUNIKAT NR 1 ZARZĄDU WOJEWÓDZTWA ŚLĄSKIEGO...). Zaangażowanie lokalnych hodowców oraz dofinansowanie hodowli lokalnych ras owiec (na terenie Jury Krakowsko-Częstochowskiej - owcy olkuskiej i wrzosówki, na terenach górskich - cakla podhalańskiego i polskiej owcy górskiej odmiany barwnej) obok zahamowania procesu sukcesji leśnej i zachowania cennych płatów muraw kwietnych (Cirsio-Brachypodion pinnati) i naskalnych (Seslerio-Festucion duriusculae), umożliwiaja również ochronę zasobów genetycznych rodzimych ras zwierząt gospodarskich (FĄFERA i KASZTELNIK 2009, BABCZYŃSKA-SENDEK 2010, BUlA i współaut. 2013, KoRCZYŃSKI 2013). Promocja tradycji pasterskich i zwiazanego $z$ nim dziedzictwa kulturowego, organizacja imprez folklorystycznych, a także rozbudowa infrastruktury turystycznej przyczyniły się do ożywienia społeczno-gospodarczego regionów Wyżyny Krakowsko-Częstochowskiej i Beskidów. Szeroka gama wyrobów regionalnych, urozmaicony krajobraz wapiennych jurajskich ostańców, czy beskidzkich hal $z$ wypasajacymi się owcami czy kozami sprawiaja, że miej- sca te sa coraz chętniej odwiedzane przez turystów. Wzrastajacy w ostatnich latach ruch turystyczny został jednak odpowiednio skanalizowany. Reorganizacja istniejacych szlaków turystycznych, wytyczenie ścieżek dydaktycznych i edukacja ekologiczna realizowana za pomoca licznych tablic, informujacych turystów o walorach jurajskiej i beskidzkiej flory oraz znaczeniu jej ochrony, czy wreszcie wprowadzone elementy małej architektury (miejsca odpoczynku, wiaty dla turystów, pojemniki na odpady) w sposób należyty zabezpieczaja cenne płaty roślinności przed nadmierna penetracja i zaśmiecaniem (FĄFERA i KASZTELNIK 2009, KOMUNIKAT 2015). Tym samym realizacja programu „Owca Plus”, łaczac potrzeby ochrony przyrody i turystyki przyczynia się do wzrostu poziomu życia lokalnych społeczności, realizując paradygmat zrównoważonego zarządzania krajobrazem kulturowym (SoBALA 2014). Sukces programu "Owca Plus" zachęcił samorzady sassiednich województw do pojęcia podobnych przedsięwzięć. Przykładem sa projekty zrealizowane w ostatnich latach w Małopolsce (Program Aktywizacji Gospodarczej i Ochrony Dziedzictwa Karpat "OWCA plus”, projekt „Karpaty Łacza”), na Lubelszczyźnie (projekt „Ochrona siedlisk trawiastych wschodniej Lubelszczyzny”) i w województwie świętokrzyskim (projekt „Ochrona cennych siedlisk przyrodniczych na Ponidziu") (BERNACKA i współaut. 2011, HAŁATKIEWICZ 2014, SOBALA 2014, SiKORA i KAWECKA 2015, SzPARA 2016, SIELEWICZ i współaut. 2017).

\section{PODSUMOWANIE}

Podejmowane w ostatnich latach działania ochrony czynnej dały w zdecydowanej większości przypadków pozytywny efekt, pozwalajac na zachowanie powierzchni odtwarzanych i użytkowanych muraw kserotermicznych. W Ojcowskim Parku Narodowym regularnie prowadzone od końca lat 80 . XX w. zabiegi ochrony aktywnej przyczyniły się do utrzymania bogatej oraz różnorodnej gatunkowo flory i fauny muraw. Ich powierzchnia wciąż jednak jest mniejsza w stosunku do tej, która występowała na ziemiach polskich na przełomie XIX i XX w. Murawy kserotermiczne, jako ekstensywnie i intensywnie użytkowane pastwiska stanowiły wówczas istotna gałaź gospodarki rolnej. W chwili obecnej trudno sobie wyobrazić możliwość utrzymania i użytkowania muraw na taka skalę, jedynie dla celów ochrony przyrody. Konieczne byłoby zatem znalezienie dla płatów roślinności kserotermicznej nowej funkcji gospodarczej (np. turystyka, promocja regionu, medycyna, farmacja, itp.), 
jednocześnie nie stojącej w sprzeczności $z$ ochrona ich wartości przyrodniczych.

\section{Streszczenie}

Murawy kserotermiczne to jedno $z$ najbardziej zagrożonych siedlisk przyrodniczych w Europie, objęte ochrona w ramach sieci Natura 2000. Zmiany w sposobie użytkowania gruntów (zalesienie, zabudowa), zaniechanie ekstensywnego użytkowania, sukcesja wtórna i brak aktywnej ochrony siedlisk (wypasanie, wykaszanie) przyczyniły się do utraty wielu cennych płatów roślinności kserotermicznej. Odtwarzanie najsilniej zdegenerowanych muraw kserotermicznych obejmuje eliminację ekspansywnych i inwazyjnych gatunków roślin zielnych, krzewów i drzew, reintrodukcję taksonów murawowych oraz transplantację dobrze zachowanych fragmentów muraw. W przypadku siedlisk dobrze zachowanych ważne jest stałe usuwanie nadmiaru gromadzącej się biomasy. Istotne znaczenie dla zachowania muraw kserotermicznych mają mechanizmy finansowe, wspierające tradycyjne pasterskie formy użytkowania rolniczego $z$ udziałem społeczności lokalnych oraz działania ukierunkowane na podnoszenie poziomu świadomości ekologicznej turystów.

\section{LITERATURA}

AGENCJA (Agencja Restrukturyzacji i Modernizacji Rolnictwa), 2016a. Pomoc unijna. http://www. arimr.gov.pl/pomoc-unijna.html (27.01.2019).

AGENCJA (Agencja Restrukturyzacji i Modernizacji Rolnictwa), 2016b. Program Rozwoju Obszarów Wiejskich 2014-2020. http://www.arimr. gov.pl/pomoc-unijna/prow-2014-2020.html (27.01.2019).

AGENCJA (Agencja Restrukturyzacji i Modernizacji Rolnictwa), 2016c. Program Rozwoju Obszarów Wiejskich 2014-2020, Działanie 10, Działanie rolno-środowiskowo klimatyczne - kampania 2017 r., Informacje - Pakiet 4. Cenne siedliska i zagrożone gatunki ptaków na obszarach Natura $2000 i$ Pakiet 5. Cenne siedliska poza obszarami Natura 2000. https://www. arimr.gov.pl/pomoc-unijna/prow-2014-2020/ dzialanie-rolnosrodowiskowo-klimatyczneoraz-rolnictwo-ekologiczne-w-2015-rokuprojekt-prow/dzialanie-10-dzialanie-rolnosrodowiskowo-klimatyczne-kampania-2017. html (27.01.2019).

AGENCJA (Agencja Restrukturyzacji i Modernizacji Rolnictwa), 2016d. Działanie 10, Działanie rolno-środowiskowo-klimatyczne - kampania 2017 r., Informacje - Pakiet 7. Zachowanie zagrożonych zasobów genetycznych zwierzat $w$ rolnictwie. https://www. arimr.gov.pl/pomoc-unijna/prow-2014-2020/ dzialanie-rolnosrodowiskowo-klimatyczneoraz-rolnictwo-ekologiczne-w-2015-rokuprojekt-prow/dzialanie-10-dzialanie-rolnosrodowiskowo-klimatyczne-kampania-2017. html (27.01.2019).

BABCZYŃSKA-SENDEK B., 2010. Wystepowanie, zagrożenia $i$ monitoring siedlisk nieleśnych na obszarach sieci NATURA 2000: Ostoja Kroczycka $i$ Ostoja Środkowojurajska wraz $z$ uwzględnieniem terenów przyległych. WFOŚSiGW w Katowicach, Katowice.

BANACH M., 2010. Utrzymanie bioróżnorodności siedlisk kserotermicznych $w$ Małopolsce. Studia i Materiały CEPL w Rogowie 25, 248-255.

BANASZAK J., CZECHOWSKA W., CZECHOWSKI W. GARBARCZYK H., SAWONIEWICZ J., WIŚNIOWSKI B., 2000. Zagrożenia $i$ perspektywy ochro- ny owadów błonkoskrzydłych (Hymenoptera). Wiad. Entomol. 18 (Supl. 2), 177-211.

BARAŃSKA K., 2013. Ochrona muraw kserotermicznych $w$ Polsce - teoria i praktyka. [W:] Utrzymanie bioróżnorodności siedlisk kserotermicznych $w$ Małopolsce. KoTOŃsKA B. (red.). Regionalna Dyrekcja Ochrony Srodowiska w Krakowie, Kraków, 29-34.

BARAŃSKA K., 2014. Podrecznik najlepszych praktyk ochrony kseroterm. Centrum Koordynacji Projektów Srodowiskowych, Warszawa.

BARAŃSKA K., CHMIELEWSKI P., CWENER A., PLUCIŃSKI P., 2010. Ochrona muraw kserotermicznych $w$ Polsce. Teoria $i$ praktyka. Wydawnictwo Klubu Przyrodników, Swiebodzin.

BARAŃSKA K., ŻMIHORSKI M., PLUCIŃSKI P., 2013. Raport $z$ projektu Ochrona muraw kseroter micznych $w$ Polsce - teoria i praktyka LIFE08 $N A T / P L / 513$. Wydawnictwo Klubu Przyrodników, Swiebodzin.

BABA W., 1999. Murawy kserotermiczne w planie ochrony Ojcowskiego Parku Narodowego. Przegl. Przyr. 10, 129-136.

BĄBA W., 2002/2003a. Ekologiczne podstawy ochrony aktywnej $i$ ksztaltowania ekosystemów muraw kserotermicznych $w$ Ojcowskim Parku Narodowym i otulinie. I. Wprowadzenie. Pradnik. Prace Muz. Szafera 13, 51-76.

BĄBA W., 2002/2003b. Ekologiczne podstawy ochrony aktywnej $i$ ksztaltowania ekosystemów muraw kserotermicznych $w$ Ojcowskim Parku Narodowym i otulinie. II. Zmiany składu florystycznego badanych poletek. Pradnik. Prace Muz. Szafera. 13, 77-94.

BĄBA W., 2002/2003c. Ekologiczne podstawy ochrony aktywnej $i$ kształtowania ekosystemów muraw kserotermicznych $w$ Ojcowskim Parku Narodowym i otulinie. III. Zmiany struktury zbiorowisk pod wpływem zastosowanych zabiegów. Prądnik. Prace Muz. Szafera. 13, 95-114.

BABA W., KompatA-BABA A., 2005. Do small-scale gaps in calcareous grasslands swards facilitate seedling establishment? Acta Soc. Bot. Pol. 74, 125-131.

BĄBA W., KUROWSKA M., KOMPAEA-BĄBA A., WILCZEK A., DŁUGOSZ J., SZAREJKO I., 2012a. Genetic diversity of populations of Brachypodium pinnatum (L.) P. Beauv.: Expansive grass in a fragmented landscape. Pol. J. Ecol. 60, 31-40.

BĄBA W., KUROWSKA M., Kompata-BĄBA A., WILCZEK A., DŁugOsZ J., SZAREJKO I., 2012b. Genetic diversity of the expansive grass Brachypodium pinnatum in a changing landscape: Effect of habitat age. Flora. 207, 346-353.

BąBA W., KalaJi H.M., Kompala-BąBA A., Goltsev V., 2016. Acclimatization of photosynthetic apparatus of tor grass (Brachypodium pinnatum) during expansion. PLoS One 11. https://doi. org/10.1371/journal.pone.0156201.

BERNACKA H., SIMINSKa E., NIEDŹWIECKI P., 2011. Alternatywne metody wykorzystania owiec. Wiad. Zoot. 49, 59-66.

Bula R., KLOCZKOWSKA A., PARUSEl J.B., ROMAŃCZYK M., 2013. Monitoring przyrodniczy Programu aktywizacji gospodarczej oraz zachowania dziedzictwa kulturowego Beskidów i Jury Krakowsko-Częstochowskiej Owca Plus na lata 2010-2014. Raport 2013. Centrum Dziedzictwa Przyrody Gôrnego Śląska, Katowice.

ChMielewski P., CZARneCKA B., KuCharCZYK M., 2014. Echium russicum J. F. Gmel. Żmijowiec czerwony. [W:] Polska Czerwona Ksiega Roślin. Paprotniki $i$ rośliny kwiatowe. KAźMIERCZAKOWA R., ZARZYCKI K., MIREK Z. (red.). IOP PAN, Kraków, 417-418. 
CIEŚlAK E., 2015. Historia migracji roślinności kserotermicznej na teren Polski południowej $w$ świetle badañ molekularnych. Fragm. Florist. Geobot. Polon. 22, 3-13.

CZARNECKA J., 2008. Spatial and temporal variability of seed bank resulting from overgroving of xerothermic grassland. Acta Soc. Bot. Pol. $77,157-166$.

CZYlOK A., ŚlusarczyK M., KuTERA M., 2013. SpoŁeczności lokalne a moźliwości ochrony cennych muraw kserotermicznych na przykładzie wybranych obszarów Natura 2000 na Wyżynie Krakowsko-Częstochowskiej. [W:] Utrzymanie bioróżnorodności siedlisk kserotermicznych $w$ Małopolsce. KoTOŃsKA B. (red.). Regionalna Dyrekcja Ochrony Środowiska w Krakowie, Kraków, 25-28.

DYREKTYWA, 2009. Dyrektywa Parlamentu Europejskiego $i$ Rady 2009/147/WE $z$ dnia 30 listopada 2009 r. $w$ sprawie ochrony dzikiego ptactwa. Dz. U. L. 20 z 26.1.2010.

DZIURA M., WOLAŃSKI P., 2013. Murawy kserotermiczne $z$ klasy Festuco-Brometea - rzadkie elementy $w$ szacie roślinnej krajobrazu rolni czego Polski. Acta Carpathica. 10, 31-36.

DzWONKO Z., 2013. Pochodzenie, przemiany $i$ znaczenie roślinności kserotermicznej $w$ Polsce. [W:] Utrzymanie bioróżnorodności siedlisk kserotermicznych $w$ Małopolsce. KOTOŃsKA B. (red.). Regionalna Dyrekcja Ochrony Środowiska w Krakowie, Kraków, 13-17.

DZWONKO Z., LOSTER S., 2008. Changes in plant species composition in abandoned and restored limestone grasslands. Acta Soc. Bot. Pol. 77, 67-75.

FĄFERA B., KASZTELNIK W., 2009. Program aktywizacji gospodarczej oraz zachowania dziedzictwa kulturowego Beskidów i Jury Krakowsko-Częstochowskiej. Zespół Ślaskiego Ośrodka Rolniczego w Częstochowie, Katowice.

FISCHER S.F., Poschlod P., BEINLICH B., 1996. Experimental studies on the dispersal of plants and animals on sheep in calcareous grasslands. J. Appl. Ecol. 33, 1206-1222.

GAWROŃSKI S., 2013. Monitoring efektów przyrodniczych prowadzonych działan ochronnych. [W:] Utrzymanie bioróżnorodności siedlisk kserotermicznych $w$ Małopolsce. KOTOŃsKA B. (red.). Regionalna Dyrekcja Ochrony Środowiska w Krakowie, Kraków, 51-62.

GEÓWNY INSPEKTORAT OCHRONY ŚRODOWISKA, 2019. Zalecenia ochronne dla typów siedlisk przyrodniczych badanych $w$ latach 2013-2014. http://siedliska.gios.gov.pl/pl/ monitoring/zalecenia-ochronne (27.01.2019).

Gus (Główny Urząd Statystyczny), 2018. Rocznik statystyczny. Ochrona Środowiska. Warszawa.

GRABOWSKI T., 2010. Turystyka $w$ środowisku muraw kserotermicznych. Probl. Ekol. Kraj. $27,431-434$.

GRABOWSKI T., 2011. Czy murawy kserotermiczne rejonu Ponidzia przetrwaja? Prace i Studia Geograficzne 46, 193-199.

HaŁATKIEWICZ T., 2014. Ochrona cennych siedlisk przyrodniczych na Ponidziu - LIFE13 NAT/ PL/000038. Zespół Świetokrzyskich i Nadnidziańskich Parków Krajobrazowych w Kielcach, Kielce.

JANICKA M., JANICKA M. A., 2015. Zbiorowiska kserotermiczne rezerwatu florystycznego „Winnica" - stan, zagrożenia i ochrona. Łąkarstwo w Polsce 18, 113-127.

JAROSZ-SOSIK M., 2013. Doświadczenia z realizacji projektu "Ochrona siedlisk przyrodniczych i gatunków na obszarach sieci Natura 2000 w województwie lubelskim. [W:] Utrzymanie bioróżnorodności siedlisk kserotermicznych $w$ Małopolsce. KOTOŃSKA B. (red.). Regionalna Dyrekcja Ochrony Środowiska w Krakowie, Kraków, 63-66.

JASTRZEBSKA J., 2013. Wpływ wypalania traw na środowisko. Acta Carpathica. 10, 67-71.

KAŹMIERCZAKOWA R., 1991. Przemiany zespołu świetlistej dabrowy $w$ rezerwacie Kwiatówka na Wyżynie Małopolskiej w ciagu 25 lat ochrony. Pradnik. Prace Muz. Szafera. 4, 39-47.

KomUNiKAT, 2015. Komunikat $n r 1$ Zarzadu Województwa Ślaskiego z dnia 13 maja 2015 r. $w$ sprawie przyjęcia programu pn. Wojewódzki Program Aktywizacji Gospodarczej oraz Zachowania Dziedzictwa Kulturowego Beskidów i Jury Krakowsko-Częstochowskiej - Owca Plus do roku 2020. Dz. U. Woj. S1. 2015, poz. 2847.

Kopeć D., Michalska-HEJduk D., 2016. Gatunki $z$ rodzaju nawłoć Solidago spp. [W:] Metody zwalczania obcych gatunków roślin występujacych na terenie Puszczy Kampinoskiej. OBIDZIŃSKI A., KOŁACZKOWSKA E., OTREBA A. (red.). Kampinoski Park Narodowy, Izabelin, 51-58.

KORCZYŃSKI T., 2013. Historia $i$ specyfika hodowli owcy olkuskiej oraz jej znaczenie $w$ ochronie zasobów genetycznych zwierzat domowych. [W:] Utrzymanie bioróżnorodności siedlisk kserotermicznych $w$ Małopolsce. KOTOŃSKA B. (red.). Regionalna Dyrekcja Ochrony Środowiska w Krakowie, Kraków, 43-46.

KORDOWSKA M., 2015. Etapy prac z zakresu ochrony cennej roślinności na przykładzie muraw kserotermicznych. Probl. Ekol. Kraj. 39, 79-86.

Kostuch R., MiszTal A., 2007. Roślinność kserotermiczna istotnym elementem bioróżnorodności Wyżyny Małopolskiej. Woda-Środowisko-Obszary Wiejskie 7, 99-110.

KRYŚCIŃSKA A., STEFANIAK A., BOMANOWSKA A., 2011. Wpływ wspinaczki skałkowej na flore naskalna Mirowskich Skat. Acta Bot. Siles. 7, 165-176.

KRZYSZTOFIAK I., 2009. Zwalczanie barszczu Sosnowskiego na Suwalszczyźnie. [W:] Inwazyjne gatunki roślin ekosystemów mokradłowych Polski. DAJDOK Z., PAWLACZYK P. (red.). Wydawnictwo Klubu Przyrodników, Swiebodzin, $138-142$.

KUCHARZYK S., 2010. Murawa kserotermiczna $z$ zawilcem wielkokwiatowym Anemone sylvestris L. na Pogórzu Przemyskim. Chrońmy Przyr. Ojcz. 66, 190-200.

KUlik M., WARDa M., GRUSZECKI T., TATARCZAK M., PATKOWSKI K., 2015. Ocena zagrożeń $i$ metod ochrony muraw kserotermicznych $z$ klasy $\mathrm{Fe}$ stuco-Brometea $w$ rezerwacie przyrody Stawska Góra. Łakarstwo w Polsce 18, 145-157.

MatuszkiEWICZ W., 2008. Przewodnik do oznaczanie zbiorowisk roślinnych Polski. Wydawnictwo Naukowe PWN, Warszawa.

MAZUR M., KUBISZ D., 2000. Ochrona owadów siedlisk kserotermicznych Polski. Wiad. Entomol. 18 (Supl. 2), 129-137.

MCHUGH J. M., 2006. A review of literature and field practices focused on the management and control of invasive knotweed (Polygonum cuspidatum, $P$. sachalinense, $P$. polystachyum and hybrids). The Nature Conservancy, Southern Lake Champlain Valley Program, West Haven.

MEDWECKA-KORNAŚ A., KoRNAŚ J., 1977. Zespoły stepów i suchych muraw. [W:] Szata roślinna Polski. SZAFER W., ZARZYCKI K. (red.). Pań- 
stwowe Wydawnictwo Naukowe, Warszawa, 352-362.

MicHALIK S., 1974. Antropogeniczne przemiany szaty roślinnej Ojcowskiego Parku Narodowego od poczatków XIX wieku do 1960 roku. Ochr. Przyr. 39, 65-154.

MichaliK S., 1990. Sukcesja wtórna półnatualnej murawy kserotermicznej Origano-Brachypodietum w latach 1960-1984 wskutek zaprzestania wypasu $w$ rezerwacie Kajasówka. Prądnik. Prace Muz. Szafera 2, 59-65.

MicHALIK S., 1993. Waloryzacja $i$ przestrzenny plan ochrony szaty roślinnej Ojcowskiego Parku Narodowego. Pradnik. Prace Muz. Szafera 7-8, 317-338.

MRÓZ W., BĀBA W., 2010. Murawy kserotermicz ne. [W:] Monitoring siedlisk. Przewodnik metodyczny, cz. I. Mróz W. (red.). Biblioteka Monitoringu Środowiska, Warszawa, 119-129.

MYDŁOWSKI M., 2016. Kierunki rozwoju i zarzadzania terenami zieleni $w$ Krakowie na lata 2017-2030. Aneks II: Ochrona Przyrody. Miejskie Centrum Dialogu, Kraków.

Nielsen C., Ravn H. P., Nentwig W., Wade M., 2005. The Giant Hogweed Best practice Man ual. Guidelines for the management and control of an invasive weed in Europe. Forest Landscape Denmark, Hørsholm.

Perglová I., Pergl J., Pyšek P., 2007. Reproductive ecology of Heracleum mantegazzianum. [W:] Ecology and Management of Giant Hog weed (Heracleum mantegazzianum). PYŠEK P. Cock M. J. W., Nentwing W., RavN H. P. (red.). CAB International, Oxfordshire, 55-73.

PERZANOWSKA J., KuJAWA-PAWLACZYK J., 2004. Murawy kserotermiczne (Festuco-Brometea). [W:] Murawy, łaki, ziołorośla, wrzosowiska, zarośla. Poradniki ochrony siedlisk i gatunków $\mathrm{Na}$ tura 2000 - poradnik metodyczny, T. 3. HER$\mathrm{BICH}$ J. (red.). Ministerstwo Srodowiska, Warszawa, 117-139.

POSCHLOD P., BONN S., 1998. Changing dispersal processes in the central European landscape since the last ice age: an explanation for the actual decrease of plant species richness in different habitats? Acta Bot. Neerl. 47, 27-44.

RAHMONOV O., PARUSEL T., 2012. Wpływ opadu roślinnego robinii akacjowej Robinia pseudoacacia $L$. na proces rozwoju gleby na obszarach zdegradowanych. Studia i Materiały CEPL w Rogowie 33, 81-92.

RATYŃSKA H., WALDON B., 2011. State of preservation of xerothermic grasslands in Kuyavian-Pomeranian region. Ann. UMCS, Biologia 66, 63-83.

ROZPORZADZENIE, 2010. Rozporzadzenie Ministra Środowiska $z$ dnia 13 kwietnia 2010 r. w sprawie siedlisk przyrodniczych oraz gatunków bedacych przedmiotem zainteresowania Wspólnoty, a także kryteriów wyboru obszarów kwalifikujacych sie do uznania lub wyznaczenia jako obszary Natura 2000. Dz. U. 2010, nr 77, poz. 510).

RozWALKA R., 2013. Co wiemy na temat fauny środowisk kserotermicznych. [W:] Utrzymanie bioróżnorodności siedlisk kserotermicznych $w$ Małopolsce. KOTOŃSKA B. (red.). Regionalna Dyrekcja Ochrony Środowiska w Krakowie, Kraków, 9-12.

SACHAJDAKIEWICZ I., MEDRZYCKI P., WÓJCIK M., PASTWA J., KŁOSSOWSKI E. 2014. Wytyczne doty czace zwalczania barszczu Sosnowskiego (Heracleum sosnowskyi) $i$ barszczu Mantegazziego (Heracleum mantegazzianum) na terenie Polski. Generalna Dyrekcja Ochrony Środowiska, Warszawa.
SiElewicZ B., POLKOWSKA M., WALCZAK K., 2017. Ochrona bioróżnorodności siedlisk trawiastych wschodniej Lubelszczyzny - cele, działania, efekty. Regionalna Dyrekcja Ochrony Środowiska w Lublinie, Lublin.

SIKORA A., KAWECKA A., 2015. Aktualny stan krajowej hodowli $i$ chowu kóz, ze szczególnym uwzględnieniem województwa małopolskiego. Wiad. Zoot. 53(4), 76-82.

SoBAla M., 2014. Krajobrazy pasterskie w Polsce $i$ Europie - wybrane typy, przykłady $i$ ich formy ochrony. Pr. Kom. Kraj. Kult. 25, 81-98.

Sosin-BZducha E., CheŁmińsKa A., SiKora J., 2012. Wypas owiec jako element czynnej ochrony Krajobrazu Wyżyny Krakowsko-Częstochowskiej. Wiad. Zoot. 50, 85-88.

SZAFER W., 1977. Szata roślinna Polski niżowej. [W:] Szata roślinna Polski. SzAFER W., ZARZYCKI K. (red.). Państwowe Wydawnictwo Naukowe, Warszawa, 17-188

SZCZEŚSIAK E., KACKI Z., 2004. Materiały do flory Kamiennego Grzbietu (Masyw Ślęży, Przedgórze Sudeckie). Acta Bot. Sil. 1, 85-90.

SzPARA K., 2016. Wspólnie dla zrównoważonego rozwoju Karpat. Poradnik o Konwencji Karpackiej. Stowarzyszenie Ekopsychologia, Zakliczyn.

TOKARSKA-GUZIK B., 2009. Metody zwalczania roślin inwazyjnych obcego pochodzenia. [W:] Inwazyjne gatunki rośli ekosystemów mokradłowych Polski. DAJDOK Z., PAWLACZYK P. (red.). Wydawnictwo Klubu Przyrodników, Świebodzin, 124-131.

TOKARSKA-GUZIK B., DAJDOK Z., ZAJAC M., ZAJAC A., URBISZ A., DANIELEWICZ W., HOEDYŃSKI C., 2012. Rośliny obcego pochodzenia $w$ Polsce ze szczególnym uwzględnieniem gatunków inwazyjnych. Generalna Dyrekcja Ochrony Środowiska, Warszawa.

TOKARSKA-GUZIK B., BZDEGA K., NOWAK T., URBISZ A., WegrzyneK B., DAJDOK Z., 2015a. Propozycja listy roślin gatunków obcych, które moga stanowić zagrożenie dla przyrody Polski $i$ Unit Europejskiej. Uniwersytet Sląski w Katowicach, Katowice.

TOKARSKA-GUZIK B., FOJCIK B., BZDEGA K., URBISZ A., NOWAK T., PASIERBIŃSKI A., DAJDOK $Z$. 2015b. Wytyczne dotyczace zwalczania rdestowców na terenie Polski. Uniwersytet Ślaski w Katowicach, Katowice.

TRĄBA C., 2014. Zróżnicowanie zbiorowisk trawiastych $w$ Polsce. Łakarstwo w Polsce 17, 127143.

UstaWA, 2004. Ustawa $z$ dnia 16 kwietnia 2004 r. o ochronie przyrody. Dz. U. 2004, nr 92, poz. 880

UstaWA, 2007. Ustawa $z$ dnia 13 kwietnia 2007 r. o zapobieganiu szkodom $w$ środowi sku $i$ ich naprawie. Dz. U. 2007, nr 75, poz. 493.

UstaWA, 2008. Ustawa $z$ dnia 3 października 2008 r. o udostepnianiu informacji o środowisku i jego ochronie, udziale spoleczeństwa $w$ ochronie środowiska oraz ocenach oddziaływania na środowisko. Dz. U. 2008, nr 199, poz. 1227.

ZAJĄCZKOWSKI K., WOJDA T., 2012. Robinia akacjowa Robinia pseudoacacia L. w gospodarczej uprawie plantacyjnej. Studia i Materiały CEPL w Rogowie 33(4), 130-135.

ZARZYCKI J., SZYMACHA A., 2006. Dynamika i zróżnicowanie przestrzenne temperatury podczas wiosennego wypalania nieleśnych zbiorowisk roślinnych. Woda-Środowisko-Obszary Wiejskie 6, 437-448. 
KOSMOS Vol. 68, 4, 599-611, 2019

\author{
ROBERT HANCZARUK ${ }^{1}$, WOJCIECH BĄBA ${ }^{2}$
}

${ }^{1}$ Institute of Biology, Biotechnology and Environmental Protection, Faculty of Natural Science, University of Silesia in Katowice, Jagiellońska 28, 40-032 Katowice, ${ }^{2}$ Department of Research and Development, Institute for Ecology of Industrial Areas, 6 Kossutha Str., 40-844 Katowice, E-mail: roberthanczaruk@gmail.com,wojciech.baba12@gmail.com

\title{
THREATS AND PROTECTION OF VALUABLE NATURAL HABITATS IN POLAND ON THE EXAMPLE OF CALCAREOUS GRASSLANDS
}

\section{Summary}

Xerothermic grasslands are one of the most endangered natural habitats in Europe, that are protected in reserves as well as Natura 2000 sites. Changes in land use (afforestation, building), cessation of traditional agricultural use (grazing, mowing) and insufficient active protection of the habitat contributed to loss of many valuable patches of the xerothermic vegetation. Restoration of the most degenerated xerothermic grasslands includes elimination of expansive and invasive herbaceous plants, shrubs and trees, as well as reintroduction of grassland taxa and transplantation of pieces of grasslands. In the case of well-preserved habitats, it is important to regularly remove of overgrowth biomass. The financial mechanism supporting traditional pastoral forms of agricultural use with the participation of the local inhabitants and activities aimed at raising the ecological awareness of tourist have important significance for the preservation of xerothermic grasslands.

Key words: active protection of nature, ecological education, land use changes, secondary succession, xerothermic grasslands 